\title{
Determinants of Market Liquidity of Shares Traded on the BM\&FBOVESPA
}

\author{
Laíse Ferraz Correia ${ }^{\dagger}$ \\ Centro Federal de Educação Tecnológica de Minas Gerais - CEFET-MG \\ Hudson Fernandes Amaral ${ }^{\Omega}$ \\ Universidade Federal de Minas Gerais - UFMG
}

\begin{abstract}
This article aims to identify determinants of liquidity of shares traded on the BM\&FBOVESPA. It was considered the influence of aspects such as the level of governance, listing on US stock markets and specific business characteristics. The concept of liquidity adopted can be simplified as the ease with which an asset is traded by its market price. The greater the difference between the price offered and the demanded on a security (bid-ask spread), the greater its illiquidity. The methodology consisted of regressions using panel data for a sample of common shares and preferred shares of non-financial companies listed on the BM\&FBOVESPA, between 1995 and 2010. The results revealed that liquidity increases with the adoption of ADRs; governance; financial slack and return on sales. Moreover, the less liquid stocks are the ones that pay more dividends.
\end{abstract}

Keywords: Stock liquidity. Corporate governance. ADR. Leverage. Dividends.

\footnotetext{
* Author for correspondence:

${ }^{\dagger}$. Doctorate in Administration from Faculdade de Ciências Econômicas da Universidade Federal de Minas Gerais - UFMG

Institution: Professor of Finance at the Centro Federal de Educação Tecnológica de Minas Gerais - CEFET-MG

Address: Av. Amazonas, Belo Horizonte - MG Brazil - E- mail: laise@dcsa.cefetmg.br Telephone: (31) 3319-6867
}

\footnotetext{
${ }^{\Omega}$ Doctorate in Sciences de Gestion from École Supérieure Des Affaires (ESA-IAE) of Université Pierre-Mendès-France (UPMF) - Grenoble - France

Institution: Professor at the Universidade Federal de Minas Gerais - UFMG

Address: Av. Antônio Carlos - Campus Pampulha, Belo

Horizonte - MG - Brazil

E-mail: hfamaral@face.ufmg.br

Telephone: (31) 3409-7031
}

Note from the editor: This article was accepted by Emerson Mainardes 


\section{INTRODUCTION}

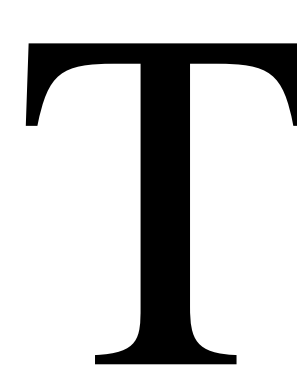

he aim of this study was to identify determining factors of market liquidity of shares traded on the São Paulo Stock Exchange (BM\&FBOVESPA), between 1995 and 2010. It was considered the influence of aspects such as the level of corporate governance, listing on US stock markets and specific characteristics of the companies in terms of dividend policy, financial structure, accounting profitability and liquidity of assets.

The concept of liquidity adopted is that of Amihud and Mendelson (1986), which can be simplified as the ease with which an asset is traded at its current market price. The greater the difference between the offered and the demanded price of a security (bid-ask spread), the greater its illiquidity. High bid-ask spreads indicate that there was a concession by the seller or a premium by the security's buyer for his orders to be executed immediately.

Liquidity refers both to the cost to negotiate the security at market price - spreads - and to the trading volume . It is observed in the most recent empirical evidence, consideration of various proxies for liquidity, given the impossibility of a single measurement reflecting the different dimensions that the concept takes. Authors such as Amihud and Mendelson (1986), Brennan and Subrahmanyam (1996), Chordia, Sarkar and Swaminathan (2005) and Kale and Loon (2011) measure illiquidity through the bid-ask spread. Alternative proxies as trading volume and turnover rate - ratio between number of shares traded and the number of shares outstanding- are also used in various analyzes, including, Datar, Naik and Radcliffe (1998) and Chordia, Roll and Subrahmanyam (2011).

Amihud and Mendelson (1988, 2000) consider that the improvement of liquidity of securities helps to reduce the cost of funds raised in the capital market by the company. Its importance in pricing thus justify the development of strategies to improve the liquidity of the shares, which, in turn, justifies the analysis of its determinants.

In the Brazilian context, there are several evidences concerning this effect: Machado and Medeiros (2012) and Bruni and Fama (1998) observed the existence of a liquidity premium; Braga and Securato (2007) and Vieira and Milach (2008), an absence of influence of liquidity on stock returns; and Correia, Amaral and Bressan (2008) and Vieira, Ceretta and Fonseca (2011), a positive association between these variables. These results highlight the importance of further studies on the relationship between liquidity and return in the Brazilian context. It is emphasized also the importance of better understanding of the determinants of liquidity of securities, purpose of this analysis. 
Altogether, the results reported here, are evidence that shares of well-governed companies with ADRs, financial slack, higher profitability on sales and that pay less dividends are more liquid.

\section{DETERMINANTS OF LIQUIDITY OF SHARES}

In the mid 80s, it began investigating liquidity as an aspect capable of positively influencing prices and therefore would allow the reduction of the cost of capital. Thus there would be interest by companies to increase the liquidity of its securities. Amihud and Mendelson (1988) point to several financial policies by which companies can increase the liquidity of its securities, such as an IPO, issue securities with standard features, list shares on organized stock markets, provide inside information to the public and decentralize the capital. Among the factors that possibly influence the liquidity of the shares, were considered in this article: admission to corporate governance segments of the BM\&FBOVESPA, internationalization through American Depositary Receipts (ADRs); dividend policy; financial structure of companies; as well as indicators of accounting profitability and financial slack.

\subsection{CORPORATE GOVERNANCE}

In the focus of agency theory, Shleifer and Vishny (1997) define corporate governance as a set of mechanisms through which investors ensure the return of their investments. In this sense, Goh, Ng and Yung (2009) argue that the main effect related to improved governance is the reduction of agency problems, which translates into higher levels of liquidity of the shares. They proposed to analyze the association between bid-ask spread and governance, mediated by: voluntary disclosure, represented by the frequency with which companies report their management forecasts; analyst coverage, the number of professionals who provide information about the company; and adverse selection, by the probability of trading based on inside information. In general, conclude that better governance in terms of independence of the board of directors and the participation of institutional investors in the ownership, improve liquidity; this relationship being mediated by higher voluntary disclosure, higher analyst coverage, and lower adverse selection. They observed that the reduction of adverse selection is the main reason for better governance be associated with higher liquidity.

The relationship between corporate governance - represented by the characteristics of boards of directors: size, level of independence and duality of the roles of chief executive officer and Chairman of the Board of Directors- and the market value of companies with shares traded on the BM\&FBOVESPA was analyzed in Gondrige, Clemente and Espejo 
(2012). Their results were inconclusive, and only found a positive association between board size and Tobin's Q. I.e., only the number of board members helps explaining the higher market value of the companies in the sample.

Chung, Elder, and Kim (2010) examined the relationship between corporate governance and stock liquidity in the North American market from the assumption that the effective governance improves financial and operational transparency and increases shareholders' ability to discern the quality of management and the true value of the company, which would increase the liquidity of its shares. For that, they developed a governance indicator based on data released by the Institutional Shareholder Services. Their results indicated that companies with good governance and transparency in information disclosure present greater liquidity in the secondary markets, lower information asymmetry and lower probability of trading based on inside information. They conclude that good governance leads to increased liquidity of the shares, which reduces the cost of equity.

The information asymmetry deepens the bid-ask spread, reduces the liquidity of securitiesand increases the opportunity cost of the company. Reducing informational advantage is a financial policy which probably increases the liquidity of the shares, since insiders are privileged over others outside investors. (AMIHUD; MENDELSON, 1988). Whereas the voluntary disclosure has benefits in terms of increased liquidity and, therefore, reducing the cost of capital, Amihud and Mendelson (2000) suggest that companies should try to make their financial reports the most transparent as possible and announce immediately new information.

In the Brazilian market, BM\&FBOVESPA launched in 2000, the Novo Mercado and Níveis Diferenciados de Governança Corporativa, "New Market" (NM) and "Differentiated Levels of Corporate Governance" (DLCG) respectively, with two main objectives: reduce the information asymmetry between investors and companies through greater transparency on the information disclosed; and reduce the cost of capital of companies that meet the new rules (AGUIAR; CORRAR; BATISTELA, 2004). Several studies have sought to identify the effects of migration on the DLCG. Aguiar, Corrar and Batistela (2004) found no significant positive change in the migration to Level 1 (N1) of corporate governance. Nevertheless, Carvalho (2003) noted that the migration of companies to some of the segments of governance of the BM\&FBOVESPA influences the valuation of shares (existence of positive abnormal returns) and increases the volume of the negotiations. The liquidity of the shares 
"before" and "after" the admission to DLCG analyzed in Martins, Silva and Nardi (2006), was associated to listing in these segments.

The most recent empirical analyzes suggest, in general, a positive effect of good governance on the liquidity of the shares on the stock market. For example, Chavez and Silva (2009), who analyze the effect of admission to the levels N1 and N2, making use of two court dates, the first being the disclosure of admission to DLCG in the press, and the second, the effective incorporation into the Corporate Governance Index, found a decrease in transaction costs and increased liquidity in both events. They found positive coefficients for returns on both dates, but significant only in the first case.

The analysis of Procianoy and Verdi (2009) suggests that companies of DLCG have higher levels of stock liquidity when compared to the traded on the traditional market of the stock exchange. Companies admitted to the N2 and NM, segments with higher disclosure requirements and governance, noted increase in liquidity, compared to the pre- admission period. Procianoy and Verdi (2009) point out, however, that companies that have joined the N1 kept similar liquidity before and after admission. The results indicate that the liquidity increase is a function of the level of disclosure and governance.

Similarly, Barbedo, Silva and Leal (2009) suggest that the fewer transactions based on inside information of shares, higher the levels of corporate governance. These evidences, however, contrary Alencar's (2005) that suggests the independence between disclosure level and cost of capital, after controlling the effect of admission to the levels of differentiated governance of the BM\&FBOVESA, trading ADRs, company size, debt and market-to-book index.

Another possible determinant of stock liquidity is the ownership structure of the company. Amihud and Mendelson (2000) argue that increasing the shareholder base is a financial policy to increase the stock liquidity. According to them, the increase in free-float reduces the bid-ask spread. In this sense, Holmstrom and Tirole (1993) argue that a greater number of investors in the market will stimulate the monitoring of the company and thus the share price will reflect more information on management performance.

\subsection{INTERNATIONALIZATION BY ISSUING ADRS (CROSS-LISTING)}

The trading of shares in the North American market through ADRs has been analyzed as a determinant of liquidity. It became, according to Pagano, Roell and Zechner (2002), an important strategic tool for companies that with the listing in foreign markets, aiming to raise 
more financial resources, increase the confidence of foreign investors, increase the level of disclosure and corporate governance, reduce capital costs and increase the liquidity of its shares. Foerster and Karolyi (1998) argue that managers of companies seek to increase the liquidity of the shares with the aim of reducing the cost of capital, and a way to promote it is to list on foreign exchanges. In the empirical analysis, they tested the effect of the listing of shares of Canadian companies in the North American market on the quoted spread and the effective spread, relative to midpoint. They documented a decrease in the cost of trading in the domestic market after the listing of ADRs; which, they claim, arises from the broadening of the investor base.

Moel (2001) argues that ADRs provide to emerging markets the advantage of increasing liquidity, transparency and ease of trading, typical of markets such as the North American. The regulatory authorities of these activities in the local market are pressured to modernize operations, improve standards of transparency of information and strengthen the legal aspect of investor protection. He points out, however, that the listing of ADRs can lead to the opposite effect, reducing the liquidity of companies that trade their securities in the domestic market, since they become less attractive to local investors. Moel (2001) found support for this hypothesis in a sample of emerging countries: the ADR issue led to the reduction in liquidity of shares and growth of local markets.

The negative effect of ADR programs has also been documented in Karolyi (2004). It was observed that, although the listing of ADRs of 12 emerging countries companies (including Brazilians) made possible the increase in flows between countries and greater integration with the global capital market, it led to the decrease of stock liquidity and the number of firms listed on the domestic market.

The effect of the issuance of ADRs for the Brazilian market was analyzed in Rodrigues (1999) and Sanvicente (2001), among others. Rodrigues (1999) observed an average 18\% increase in the liquidity of the 37 stocks that had launched ADRs, and the increase is significant at the $5 \%$ level for 20 of the 37 shares. Sanvicente (2001), sought to test the effects of trading ADRs on the quality of the Brazilian stock market (IBOVESPA) in terms of trading volume, price volatility and market value, found that both companies and the Brazilian market, in general, are benefited by trading ADRs: it was observed an increase of the turnover and market value of the shares. Recently, Neves and Lemes (2009) analyzed the effects on return and stock liquidity in the events: admission to the NM; and issuance of ADRs. No significant differences were observed in the return of firms that issue ADRs in relation to 
those that are listed in the NM; nor in the behaviour of the average stock liquidity of these companies.

\subsection{FIRM LEVEL CHARACTERISTICS}

As discussed by Amihud and Mendelson (1988), the bid-ask spread is determined, at least in part, endogenously by the company. That is, the specific characteristics of firms affect the liquidity and the return of their securities. Empirical evidence of the association between dividend policy and stock liquidity are presented in Banerjee, Gatchev and Spindt (2007) and Griffin (2010). The first found a lower probability of the holders of more liquid shares receive dividends. They point out also that the increase in liquidity of shares in the United States, over time, explains most of the companies' propensity to pay lower dividends. From an international analysis, Griffin (2010) found that, in many cases, the relationship between the liquidity of the shares and the dividend paid is reversed; Consistent with the results of Banerjee, Gatchev and Spindt (2007). For these authors, dividends serve as compensation for the lower liquidity of shares.

The relationship between liquidity and capital structure of firms was analyzed in Lesmond, O'Connor and Senbet (2008) and Lipson and Mortal (2009). The former argue that the substitution of debt for equity increases the information asymmetry and therefore increases the cost of liquidity - bid-ask spread. The analysis of a sample of non-financial companies that leveraged their capital structure showed that financial leverage leads to increased stock liquidity, decreases the probability of trading based on inside information and decreases the cost of capital. Instead, Lipson and Mortal (2009) argue that stock liquidity reduces the required return rate on equity, reducing the total cost of capital. Thus, it is expected that companies become less leveraged and prefer to use a larger share of equity in their capital structure. They corroborate this hypothesis: companies whose shares are more liquid are less leveraged and, when raising capital in the market, they prefer to do it issuing equity.

Gopalan, Kadan and Pevzner (2012) developed a model that relates stock liquidity and liquidity of the assets of the company. Empirically, they found a significant positive relationship between these indicators. The relation presented was stronger for companies with lower probability to reinvest its net assets in uncertain investments, that is, for those who had lower growth opportunities or financial constraints to raise capital from external resources; according to the model.

The specific characteristics of firms that determine the level of liquidity of the shares of 
European companies, measured by the liquidity index (IL) - first component obtained in the principal components analysis - were analyzed in Francisco (2010). The IL incorporates the liquidity proxies: ILLIQ of Amihud (2002), turnover, number of trades, volume of transactions and value of transactions. Relationships documented by Francisco (2010) were: the larger the firm size, the greater the liquidity of the shares; the greater the amount of shares outstanding (free float), greater liquidity; the higher the financial leverage, the greater the liquidity of the shares; and the smaller the accounting profitability, the greater the liquidity of the shares, although statistical significance has not been shown to be strong on these last two relations. That is, the liquidity of the shares of the analyzed sample is mainly associated to the size, to shareholder base and the debt ratio of the company.

Recently, Kale and Loon (2011) showed that the liquidity of the shares represented by the proxies ILLIQ of Amihud (2002), quoted spread and effective spread (relative to the midpoint), is positively associated with market power - measured by the relationship between the company's operational profit and the sales and by market share, after controlling the effect of factors such as asymmetric information, institutional ownership, financial leverage and advertising expenses. Their results also revealed that the stock liquidity decreases with the level of financial leverage and increases with the participation of institutional investors in the ownership and the size of the company, proxy for information asymmetry.

In short, stock liquidity is related to: level of investor protection; transparency of information; shareholder base, that is, the dispersion of ownership; and specific characteristics of the companies as dividend policy; debt ratio; liquidity of assets and profitability ratios.

\section{METHODOLOGY}

\subsection{SAMPLE AND DATA}

From the list of all common and preferred shares of companies listed on the BM\&FBOVESPA, between 1995 and 2010, with active or cancelled registration, were excluded the companies of the financial sector, in order to use in the analysis profitability indicators such as the return on equity - ROE, whose meaning is different for this sector. Having the sample taken, were collected the necessary data to calculate the variables that refer to liquidity of the shares, the admissionto the governance levels of the BM\&FBOVESPA, the listing on US stock markets NASDAQ, AMEX and NYSE using levels 2 and 3 ADR programs, to dividend policy, the financial performance of companies. With the exception of information on admission to the governance levels, obtained from historical data contained in the BM\&FBOVESPA site on the internet, the required information has been obtained in 
Economática. All economic-financial data were deflated by the General Price Index - Internal Availability (IGP-DI).

\subsection{VARIABLES AND ESTIMATION METHOD}

In this section, we present the analysis methods of the determinants of liquidity. The dependent, independent and control variables are described in Table 1.

\subsubsection{Method of construction of the liquidity index (IL)}

To build the liquidity index, we used the Nagar and Basu (2002) methodology, that consists of running a principal component analysis of all proxies of liquidity, obtain all principal components $(K)$ and calculate a weighted average of them, being their variances (eigenvalues of the correlation matrix R) weights. Once having the principal components, it was calculated the liquidity index (IL).

$$
I L=\left[\left(\lambda_{1} P C_{1}+\lambda_{2} P C_{2}+\ldots+\lambda_{k} P C_{k}\right) /\left(\lambda_{1}+\lambda_{2}+\ldots+\lambda_{k}\right)\right]
$$

Identification model of the determinants of stock liquidityInitially, it was tested the influence of corporate governance, $\mathrm{ADR}$ and financial indicators of companies on the liquidity of the shares, using quarterly data.

$$
\begin{aligned}
\operatorname{LIQUIDITY}_{i t}= & \beta_{0}+\beta_{1} N 1_{i t}+\beta_{2} N 2_{i t}+\beta_{3} N M_{i t}+\beta_{4} A D R_{i t}+\beta_{5} E x i g / P L_{i t}+ \\
& \beta_{6} L G_{i t}+\beta_{7} R O E_{i t}+\beta_{8} M L_{i t}+\varepsilon_{i t}
\end{aligned}
$$

Where: LIQUIDITY it represents, alternately: bid-ask, Quoted_f, Quoted_m, Espread, Espread_m, Espread_f, spread_amort, turnover_qneg, turnover_qt, volume.

As the ownership concentration data and dividend yield were available on an annual basis, we estimate equation (3) to test its relation to liquidity.

$$
\begin{aligned}
\operatorname{LIQUIDITY}_{i t}= & \beta_{0}+\beta_{1} N I_{i t}+\beta_{2} N 2_{i t}+\beta_{3} N M_{i t}+\beta_{4} A D R_{i t}+\beta_{5} E x i g / P L_{i t}+ \\
& \beta_{6} L G_{i t}+\beta_{7} R O E_{i t}+\beta_{8} M L_{i t}+\beta_{9} D Y_{i t}+\beta_{10} A C 3_{i t}+\varepsilon_{i t}
\end{aligned}
$$


Table 1 - Dependent and independent variables and control factors

\begin{tabular}{|c|c|c|c|}
\hline & VARIABLE & DEFINITION & FORMULA \\
\hline \multirow{11}{*}{ 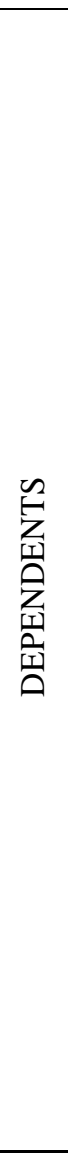 } & bid-ask spread & $\begin{array}{l}\text { Natural logarithm of the difference between } \\
\text { the maximum and minimum prices. }\end{array}$ & bidask $=\ln [$ Maximum - Minimum $]$ \\
\hline & Quoted_m & $\begin{array}{l}\text { Spread relative to the average price (Quoted } \\
\text { spread): Relation between the difference of } \\
\text { the maximum and minimum prices and the } \\
\text { midpoint (arithmetic mean of the maximum } \\
\text { and minimum prices). }\end{array}$ & Quoted ${ }_{-} m=\frac{\lfloor\text { Maximum }- \text { Minimum }\rfloor}{\text { Midpoint }}$ \\
\hline & Quoted_f & $\begin{array}{l}\text { Spread on the closing price (Quoted spread): } \\
\text { ratio between the difference of maximum and } \\
\text { minimum price and the closing price. }\end{array}$ & Quoted $_{-} f=\frac{\lfloor\text { Maximum }- \text { Minimum }\rfloor}{C l o \sin g}$ \\
\hline & Espread & $\begin{array}{l}\text { Absolute value of the difference between the } \\
\text { closing price of the share and midpoint. }\end{array}$ & Espread $=\not l o$ sin $g-$ Midpoint \\
\hline & Espread_m & $\begin{array}{l}\text { Absolute value of the difference between the } \\
\text { closing price of the share and the midpoint } \\
\text { divided by the value of the midpoint. }\end{array}$ & Espread_m $m=\frac{\text { Clo } \sin g-\text { Midpoint }}{\text { Midpoint }}$ \\
\hline & Espread_f & $\begin{array}{l}\text { Absolute value of the difference between the } \\
\text { closing price of the share and the midpoint } \\
\text { divided by the closing price of the share. }\end{array}$ & Espread $_{-} f=\frac{\text { Clo } \sin g-\text { Midpoint } \mid}{C l o \sin g}$ \\
\hline & s_amort- & Effective spread divided by the closing price & $\mid$ Closin $g-$ Midpoint $\left.\right|_{\times}$ \\
\hline & $\begin{array}{l}\text { amortized } \\
\text { Spread }\end{array}$ & $\begin{array}{l}\text { multiplied by the turnover of the security - } \\
\text { amount of shares traded (Q) on the amount of } \\
\text { shares outstanding (QOUTS). }\end{array}$ & Closing \\
\hline & Turnover_qt & $\begin{array}{l}\text { Number of shares traded as a fraction of the } \\
\text { number of shares outstanding. }\end{array}$ & turnover_qt $=Q / Q_{\text {ouTS }}$ \\
\hline & Turnover_qneg & $\begin{array}{l}\text { Number of trades with the stock as a fraction } \\
\text { of the number of shares outstanding. }\end{array}$ & turnover_qneg $=Q_{\text {TRADE }} / Q_{\text {OUTS }}$ \\
\hline & Volume & Natural logarithm of the cash trading volume. & volume_qt $=\ln ($ volume $)$ \\
\hline \multirow{4}{*}{ 突 } & N1 & \multicolumn{2}{|c|}{$\begin{array}{l}\text { Level 1: (1) whether the company joined the level } 1 \text { segment of corporate governance of } \\
\text { the BM\&FBOVESPA; }(0) \text {, otherwise. }\end{array}$} \\
\hline & $\mathrm{N} 2$ & \multicolumn{2}{|c|}{$\begin{array}{l}\text { Level 2: (1) whether the company joined the level } 2 \text { segment of corporate governance of } \\
\text { the BM\&FBOVESPA; }(0) \text {, otherwise. }\end{array}$} \\
\hline & NM & \multicolumn{2}{|c|}{$\begin{array}{l}\text { New Market: (1) if the company has joined the the New Market segment of corporate } \\
\text { governance of BM\&FBOVESPA; }(0) \text {, otherwise. }\end{array}$} \\
\hline & $\mathrm{ADR}$ & \multicolumn{2}{|c|}{$\begin{array}{l}\text { Dummy variable: (1) whether the company maintains an ADR program level } 2 \text { or } 3 \text { in a } \\
\text { North American stock exchange; }(0) \text {, otherwise. }\end{array}$} \\
\hline \multirow{6}{*}{ 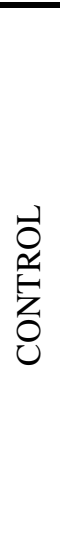 } & $\overline{\mathrm{DY}}$ & \multicolumn{2}{|c|}{$\begin{array}{l}\text { Dividend yield: ratio between the dividend paid per share in the prior year and the share } \\
\text { price at the end of the fiscal year. }\end{array}$} \\
\hline & $\mathrm{AC} 3$ & \multicolumn{2}{|c|}{ Percentage of total capital held by the three major shareholders. } \\
\hline & Exig/PL & $\begin{array}{l}\text { Financial Leverage: ratio between liabilities } \\
\text { and equity (PL). }\end{array}$ & Exig / PL = Liabilities/Equity \\
\hline & LG & $\begin{array}{l}\text { Overall liquidity of the company: ratio of the } \\
\text { sum of current assets (AC) with long-term } \\
\text { assets (RLP) and the sum of current liabilities } \\
\text { (PC) with non-current liabilities (PNC). }\end{array}$ & $L G=\mathrm{AC}+\mathrm{RLP} / \mathrm{PC}+\mathrm{PNC}$ \\
\hline & ML & $\begin{array}{l}\text { Net margin: ratio between the net income and } \\
\text { net sales. }\end{array}$ & $M L=\mathrm{LL} / V L$ \\
\hline & ROE & $\begin{array}{l}\text { Return on equity: ratio between net income } \\
\text { and equity. }\end{array}$ & $R O E=L L / P L$ \\
\hline
\end{tabular}

Note: Corwin and Schultz (2012) argue that the maximum daily prices are almost always negotiations initiated by buyers and the minimum, by sellers. Measured in this way, however, the bid-ask spread contains both components of liquidity as volatility. 


\section{RESULTS}

First of all, it was estimated the relationship between liquidity of shares, DLCG of BM\&FBOVESPA, ADR, debt, accounting profitability and liquidity of assets. At this stage, we considered quarterly data, since the financial statements are published quarterly and annually and this research uses variables that come from them. In addition, as data on the concentration of ownership of companies and dividend yield were available only on an annual basis, the models to test the relationship between these variables and the liquidity of shares were estimated, again, with annual data.

The correlation matrix of the variables showed that in general the variables of liquidity correlates significantly, indicating the existence of joint variations; except the amortized spread, which was significantly associated only to the bid-ask. The highest levels of correlation between the variables of liquidity are among Quoted spread and Espread, calculated based on the closing price, suggesting the similarity of these proxies.

The data revealed the existence of negative and significant correlations between the level of governance N1 and most variables of spread (except the bid-ask). Similarly, the N2 level was found to be inversely and significantly correlated with variables of spread (except Espread and amortized spread). That is, generally, inverse correlations were observed between N1 and N2 levels of governance of the BM\&FBOVESPA and the cost of transacting, expressed by proxies: Quoted_m, Espread_m and Espread_f. To the NM level, correlations are diverse: negatively correlated with Espread; and positively correlated with bid-ask, and Quoted_m Quoted_f.

Furthermore, it was found that correlations among the independent variables are not high. We observed negative and significant correlations between Quoted_f, Espread_m and Espread_f and ADR, indicating that the shares of Brazilian companies listed on a North American stock market have greater liquidity in the domestic market. Also are found negative correlations between accounting profitability (ROE) and the cost of transacting, expressed by the Quoted spread and Espread. Instead, there is a direct correlation between ROE and bidask. Regarding the correlation between the independent variables: governance, ADR, asset liquidity, financial leverage, return on sales and return on equity, no high correlations were found. The highest coefficient between these variables is 0.32 , suggesting no multicollinearity problems.

In Table 1, we observe a negative and significant relationship between N2 and Quoted spread - measured by Quoted_f. When considering effective spreads, we find the same 
association; there is also a negative and significant relationship between $\mathrm{N} 2$ and effective spread in absolute terms - Espread - and relative, Espread_f and Espread_m. These results indicate that the shares of companies with governance N2 are, on average, more liquid. This finding is similar to those observed in Chavez and Silva (2009). For NM, more demanding level of governance, there is negative and significant association only with Quoted_f, Espread_f and Espread_m. Contrary to expectations, there is a direct and significant association between all levels of governance and the bid-ask spread and also between N1 and Espread (TAB. 1). In large part, the data suggest that liquidity increases with the strictest standards of governance, which give greater protection to investors from the market and thus corroborate the results of Carvalho (2003), Martins, Silva and Nardi (2006), Chavez and Silva (2009) and Procianoy and Verdi (2009). The governance increases investor confidence, which translates into less difficult to transact securities.

Contrary to expectations, the results of models (1) and (4) of Table 1 show a positive and significant relationship between ADR and bid-ask and Espread, suggesting that companies with shares listed on North American stock exchange have lower liquidity of their shares in the domestic market than those that do not have this type of trading. This evidence offers support to the arguments of negative effect of ADR listing on the liquidity of shares in the domestic market, as well as to the results of Moel (2001) and Karolyi (2004) for a sample of emerging countries. In other models, are not found significant relationship between the variables of liquidity and ADR.

The models (1), (2), (3), (5) and (6) of Table 1 show that the greater the liquidity of the assets of the company, the greater the liquidity of its shares, as noted in Gopalan, Kadan and Pevzner (2012). The overall liquidity is associated negatively and significantly to variables of transaction costs (except Espread and amortized spread). This result reveals that companies with greater financial slack have more liquid stocks in the capital market. With the exception of the estimates from specification (7), the data suggest also that the higher the return on sales of the company, the greater the liquidity of shares. That is, it is observed, in large part, an inverse and significant relationship between profitability of the company's sales and the cost to transact their shares. These results suggest that shares of companies with better financial performance are more attractive to investors in the Brazilian stock market, which is reflected in the levels of liquidity of its shares.

The models in Table 1 are fixed effects, given the statistical significance of the specific effects of the cross-section units and superiority of this estimator suggested by the Hausman 
test, except for the model (4). The p values of the test of Wooldridge (2002) reject the null hypothesis of no autocorrelation; and p values for the test of Baum (2001) rejects the null hypothesis of homoscedastic variances. The model (7) was obtained from pooled-OLS estimator, once the specific effects were not significant. In this case, the $p$ value of the autocorrelation test of Arrelano and Bond (1991) rejects the null hypothesis of no autocorrelation; and the $\mathrm{p}$ value of the heteroscedasticity test of Breusch and Pagan rejects the null hypothesis of homoscedastic variances. All standard errors were obtained by the procedure of Driscoll and Kraay (1998), which corrects for heteroscedasticity and the different types of dependency between the cross-section (shares) units, that is, autocorrelation.

When liquidity is measured by trading volume, positive and significant correlations between all levels of governance and the trading volume are observed, as expected. We also observed significant positive correlations with ADR. That is, companies listed on North American stock exchanges have higher trading volume in the domestic market than those that negotiate their securities only in the Brazilian stock market. The negative and significant correlation between financial leverage and trading volume suggests that the greater the financial risk, the lower the market liquidity of the shares, similar to that observed in Lipson and Mortal (2009) and Kale and Loon (2011). Rather, the higher the return on shareholders' equity, the greater the liquidity of shares. These data indicate, in part, that the economic and financial performance of the company affects the trading activity of its shares.

Table 2 represents the liquidity of shares by measures of trading volume, absolute and relative. Regarding trading volume relative to free-float, given by the turnover, we found a positive and significant relationship with $\mathrm{N} 2$ and NM. The obtained estimates for specification (3) show a positive and significant association between all levels of governance and the trading volume, indicating that the better the governance, the greater the liquidity of the shares on the market, as observed in other studies on the Brazilian market, such as Carvalho (2003), Martins, Silva and Nardi (2006), Chavez and Silva (2009) and Procianoy and Verdi (2009). Results in Table 2 suggest that, in general, the trading volume of the shares is on average higher for companies of more demanding segments of governance. They also indicate that the observed relationship between liquidity and governance depends on the proxy used to represent liquidity.

The models (1) to (3) show that companies whose shares are listed not only in the Brazilian stock market, but also on American exchanges have higher share trading volume on the domestic market, given the positive and significant association between ADR and 
turnover_qt, turnover_qneg and volume (TAB. 2). These evidences are consistent with those of Rodrigues (1999), Sanvicente (2001) and Neves and Lemes (2009), suggesting that the greater liquidity of shares listed both on the domestic and North American stock market. The results in Table 2 do not support the negative and significant correlations between financial leverage and trading volume. They also do not corroborate the association between the profitability of equity and the liquidity of shares, suggested by correlations (TAB. 2).

The models are fixed effects, given the statistical significance of the specific effects of the cross-section and superiority of this estimator suggested by the Hausman test, except for the model (1). The p values of the test of Wooldridge (2002) reject the null hypothesis of no autocorrelation; and p values of Baum (2001) test rejects the null hypothesis of homoscedastic variances. All standard errors were obtained by the Driscoll and Kraay (1998) procedure, which corrects for heteroscedasticity and the different types of dependency between crosssection units (shares) - the autocorrelation.

To test the influence of dividend yield and concentration of ownership on liquidity, it was estimated the equation 3, for an annual data base, given that these two variables were only available in this time period. In the correlation structure, we observed significant positive associations between concentration of ownership and costs of transacting expressed by Quoted_f and Espread_f. In contrast, significant positive correlations were recorded with bidask and Espread. That is, measures of liquidity show correlations with the concentration of ownership in the expected direction, whereas the correlations with the variables expressed in absolute terms are the opposite of the expected. For the dividend yield, there are negative and significant correlations with Quoted_f, Quoted_m and Espread_m, suggesting that more liquid stocks pay more dividends.

It is observed in Table 3 a positive and significant relationship between ownership concentration and the Espread, indicating that, for this variable, the higher the concentration of ownership in the hands of the three largest shareholders, the lower the liquidity of shares (TAB. 3). This result supports the literature, suggesting that large shareholders reduce the liquidity of shares. For the dividend yield, unlike the relationships suggested by correlations, there were significant positive relationships with Quoted_f and Espread_f. These results are consistent with those of Banerjee, Gatchev and Spindt (2007) and Griffin (2010), that suggests that less liquid stocks are best dividend payers (TAB. 3).

In table 3, models (3), (6) and (7) were obtained by the pooled-OLS estimator, given the statistical insignificance of fixed effects. The $\mathrm{p}$ values of Arrelano and Bond 
autocorrelation test do not allow rejecting the null hypothesis of no autocorrelation. The $\mathrm{p}$ values of the Breusch and Pagan heteroskedasticity test rejects the null hypothesis of homoscedastic variances. The models (1), (2), (4) and (5) are fixed effects, once the crosssection units specific effects are significant and the Hausman's test p-value indicates the superiority of this estimator, except in specification (1); the p values of test of Baum (2001) rejects the null hypothesis of homoscedastic variances; and for model (2), the p values of the test of Wooldridge (2002) reject the null hypothesis of no autocorrelation. All standard errors were obtained by the procedure of Driscoll and Kraay (1998), which corrects for heteroscedasticity and the different types of dependency between cross-section units.

When liquidity is represented by the trading volume, it is observed a significant and negative correlation between the total percentage of shares in the hands of the three major shareholders of the company and the financial volume. I.e., companies in which the capital structure is concentrated, have lower liquidity of its shares in the market. There were also found negative and significant correlations between dividend yield and relative trading volume, expressed by turnover_qt and turnover_qneg. These results suggest that the lower the market liquidity of the shares, the greater the compensation in the form of dividends.

As in the correlation matrix, the specifications (1) through (3) of Table 4 show an inverse and significant relationship between trading volume and the concentration of capital in the hands of the three major shareholders. I.e., the more concentrated the ownership of the company, the lower the liquidity of its shares on the stock market. This evidence corroborates the arguments of Amihud and Mendelson (2000) that the increase in the shareholder base of a company is a financial policy by which the liquidity of the shares could be increased. The results reported here are in that sense, since they indicate that stocks of companies with more dispersed ownership are more liquid (TAB. 4).

Contrary to that suggested by correlations between liquidity and dividend yield, there was no significant association between these variables for the panel data regression models (TAB. 4). Thus, there is no evidence that the companies on which shares have lower trading volumes are those in which direct compensation to shareholders in the form of dividends is higher.

The models (1) and (2) were obtained by the pooled-OLS estimator, given the insignificance of the specific effects. The $\mathrm{p}$ values of the autocorrelation test of Arrelano and Bond (1991) do not allow rejecting the null hypothesis of no autocorrelation. The p values of the heteroskedasticity test of Breusch and Pagan rejects the null hypothesis homoscedastic 
variances. The model (3) was obtained by fixed effects, once the unit specific effects are significant and the p-value of Hausman test indicates the superiority of this estimator; the $p$ values of the test of Wooldridge (2002) reject the null hypothesis of no autocorrelation; pvalues of the test of Baum (2001) reject the null hypothesis of homoscedastic variances. All standard errors were obtained by the procedure Driscoll and Kraay (1998) that corrects for heteroscedasticity and the different types of dependency between cross-section units.

Table 1 - Relationship between spreads, DLCG, ADR, the company's liquidity, financial leverage and accounting profitability

\begin{tabular}{|c|c|c|c|c|c|c|c|}
\hline & $\begin{array}{c}\text { (1) } \\
\text { Bidask }\end{array}$ & $\begin{array}{c}\text { (2) } \\
\text { Quoted_f }\end{array}$ & $\begin{array}{c}\text { (3) } \\
\text { Quoted_m }\end{array}$ & $\begin{array}{c}\text { (4) } \\
\text { Espread }\end{array}$ & $\begin{array}{c}\text { (5) } \\
\text { Espread_f }\end{array}$ & $\begin{array}{c}\text { (6) } \\
\text { Espread_m }\end{array}$ & $\begin{array}{c}(7) \\
\text { s_amort }\end{array}$ \\
\hline N1 & $0.919^{* * *}$ & -0.0302 & -0.0161 & $0.442^{* * * *}$ & -0.00806 & -0.00476 & -0.178 \\
\hline$N 2$ & $0.219^{*}$ & $-0.0608^{*}$ & -0.0410 & $-2.677^{* *}$ & $-0.0241^{*}$ & $-0.0243^{* *}$ & -0.217 \\
\hline$N M$ & $1.041^{* * *}$ & $-0.0565^{*}$ & -0.0251 & -0.266 & $-0.0262^{* *}$ & $-0.0220^{* *}$ & -0.232 \\
\hline$A D R$ & $0.431^{* * *}$ & -0.0253 & -0.0262 & $0.585^{* * *}$ & -0.00627 & -0.00786 & -0.200 \\
\hline Exig/PL & -0.00000399 & $2.39 \mathrm{e}-08$ & 0.000000452 & -0.00000613 & $-3.72 \mathrm{e}-08$ & $9.24 \mathrm{e}-08$ & -0.000000209 \\
\hline$L G$ & $-0.000412^{* * *}$ & $-0.000169^{* * *}$ & $-0.000124^{* * *}$ & -0.0000850 & $-0.0000815^{* * * *}$ & $-0.0000684^{* * *}$ & -0.000315 \\
\hline$R O E$ & -0.000157 & -0.0000259 & -0.0000166 & 0.000481 & -0.00000752 & -0.00000737 & 0.000358 \\
\hline$M L$ & $-4.56 \mathrm{e}-12^{* * *}$ & $-1.06 \mathrm{e}-12^{* * *}$ & $-5.66 \mathrm{e}-13^{* * *}$ & $-5.29 \mathrm{e}-13^{* *}$ & $-1.93 \mathrm{e}-13^{*}$ & $-1.67 e-13^{*}$ & $-9.73 e-13$ \\
\hline _cons & $-0.335^{* * *}$ & $0.360^{* * *}$ & $0.320^{* * *}$ & $5.006^{* * * *}$ & $0.112^{* * * *}$ & $0.105^{* * *}$ & 0.288 \\
\hline r2_w & 0.0412 & 0.00176 & 0.00153 & 0.0000453 & 0.000988 & 0.00166 & \\
\hline $\mathrm{F}$ & 123.5 & 35.14 & 10.40 & 12.00 & 22.63 & 21.24 & 3.913 \\
\hline $\mathrm{N}$ & 21704 & 21168 & 23303 & 21168 & 21168 & 21168 & 20941 \\
\hline
\end{tabular}

Note: The asterisks indicate the significance levels: "p<0,05," $p<0,01, \quad p<0,001$.

Table 2 - Relationship between trading volume, DLCG, ADR, the company's liquidity, financial leverage and accounting profitability

\begin{tabular}{|c|c|c|c|}
\hline & $\begin{array}{c}\text { (1) } \\
\text { turnover/qt }\end{array}$ & $\begin{array}{c}\text { (2) } \\
\text { turnover/qneg }\end{array}$ & $\begin{array}{c}\text { (3) } \\
\text { Volume }\end{array}$ \\
\hline N1 & 0.0230 & 0.0000423 & $0.810^{* * * *}$ \\
\hline$N 2$ & $0.0695^{* * *}$ & $0.000111^{* * *}$ & $0.921^{* * *}$ \\
\hline$N M$ & $0.251^{* * *}$ & $0.000200^{* * *}$ & $3.997^{* * *}$ \\
\hline$A D R$ & $0.111^{* * *}$ & $0.0000713^{* * *}$ & $1.272^{* * *}$ \\
\hline Exig/PL & 0.0000386 & $2.65 \mathrm{e}-10$ & 0.00000303 \\
\hline$L G$ & 0.000272 & $5.50 \mathrm{e}-09$ & -0.00208 \\
\hline$R O E$ & 0.00304 & $3.66 \mathrm{e}-09$ & 0.0000556 \\
\hline$M L$ & $1.47 \mathrm{e}-13$ & $3.47 \mathrm{e}-19$ & $-2.68 e-12$ \\
\hline _cons & 2.016 & $0.0000117^{* * *}$ & $0.922^{* * *}$ \\
\hline$r 2 \_w$ & 0.00000187 & 0.00451 & 0.0790 \\
\hline$F$ & 21.56 & 28.71 & 272.9 \\
\hline$N$ & 33221 & 33221 & 22031 \\
\hline
\end{tabular}

Note: The asterisks indicate the significance levels: " $p<0,05, " p<0,01, " p<0,001$. 
Table 3 - Relationship between spreads, DLCG, ADR, dividend yield, concentration of ownership and financial indicators

\begin{tabular}{|c|c|c|c|c|c|c|c|}
\hline & $\begin{array}{c}\text { (1) } \\
\text { Bid-ask }\end{array}$ & $\begin{array}{c}\text { (2) } \\
\text { Ouoted } f\end{array}$ & $\begin{array}{c}\text { (3) } \\
\text { Ouoted } m\end{array}$ & $\begin{array}{c}\text { (4) } \\
\text { (a) }\end{array}$ & $\begin{array}{c}\text { (5) } \\
\text { Espread } f\end{array}$ & $\begin{array}{c}\text { (6) } \\
\text { Fsread }\end{array}$ & (7) \\
\hline N1 & $1.631^{* * * *}$ & 0.460 & -0.0165 & $7.384^{* * *}$ & 0.0913 & 0.0401 & 0.0995 \\
\hline$N 2$ & -0.177 & 0.271 & -0.0110 & $-5.364^{* * *}$ & -0.0605 & -0.00829 & 0.00711 \\
\hline$N M$ & $1.173^{* * * *}$ & $0.320^{*}$ & 0.0856 & $-2.661^{* * *}$ & 0.105 & 0.0690 & 0.158 \\
\hline$A D R$ & 0 & 0 & -0.0899 & 0 & 0 & -0.0257 & -0.0134 \\
\hline$A C 3$ & -0.000396 & -0.0140 & 0.00155 & $0.0512^{*}$ & -0.00431 & 0.000505 & -0.00197 \\
\hline$D Y$ & 0.0179 & $0.0283^{* * *}$ & -0.00602 & -0.0289 & $0.00752^{*}$ & -0.00222 & -0.00279 \\
\hline Exig/PL & $0.00228^{* * *}$ & 0.000160 & 0.0000954 & $0.00761^{* * * *}$ & -0.000115 & 0.0000581 & -0.0000413 \\
\hline$L G$ & -0.373 & -0.292 & $-0.0150^{* *}$ & -0.187 & -0.136 & $-0.00458^{* *}$ & $-0.00629^{*}$ \\
\hline$R O E$ & $0.0147^{* * *}$ & $0.00425^{* * *}$ & -0.0000546 & $0.0466^{* * * *}$ & 0.00101 & -0.000127 & 0.000275 \\
\hline$M L$ & $-0.00689^{* * * *}$ & $-0.00207^{* * * *}$ & $-0.000645^{*}$ & $-0.0257^{* * * *}$ & $-0.000653^{*}$ & -0.000196 & -0.000185 \\
\hline _cons & 0.473 & $1.932^{*}$ & $0.637^{* * * *}$ & -1.541 & $0.777^{* * *}$ & $0.171^{* * * *}$ & $0.280^{* *}$ \\
\hline r2_w & 0.360 & 0.253 & & 0.431 & 0.181 & & \\
\hline F & 99.64 & 223.6 & 52.66 & 79.58 & 25.23 & 19.48 & 281.7 \\
\hline $\mathrm{N}$ & 231 & 233 & 233 & 233 & 233 & 233 & 231 \\
\hline
\end{tabular}

Note: The asterisks indicate the significance levels: $* \mathrm{p}<0,05, * * \mathrm{p}<0,01, * * * \mathrm{p}<0,001$.

Table 4 - Relationship between volume, DLCG, ADR, dividend yield, concentration of ownership and financial indicators

\begin{tabular}{|c|c|c|c|}
\hline & $\begin{array}{c}\text { (1) } \\
\text { turnover_qt }\end{array}$ & $\begin{array}{c}\text { (2) } \\
\text { turnover_qneg }\end{array}$ & $\begin{array}{c}\text { (3) } \\
\text { Volume }\end{array}$ \\
\hline$N 1$ & -0.318 & 0.0000790 & $2.458^{* * *}$ \\
\hline$N 2$ & 0.119 & 0.000703 & $2.664^{* * *}$ \\
\hline$N M$ & 0.269 & $0.000475^{*}$ & 1.137 \\
\hline$A D R$ & 0.529 & 0.000575 & 0 \\
\hline$A C 3$ & $-0.0167^{* * *}$ & $-0.00000553^{* *}$ & $-0.0316^{* *}$ \\
\hline$D Y$ & -0.00210 & -0.00000940 & 0.0117 \\
\hline Exig/pl & -0.0000534 & $-1.36 \mathrm{e}-08$ & $0.00286^{* * *}$ \\
\hline Liq-ger & $-0.0218^{*}$ & -0.000000434 & $-0.331^{* *}$ \\
\hline$R O E$ & 0.00165 & $0.00000121^{*}$ & $0.0234^{* * * *}$ \\
\hline$M L$ & -0.000811 & $-0.000000656^{*}$ & $-0.0115^{* * *}$ \\
\hline _cons & $1.648^{* * *}$ & $0.000595^{* *}$ & $4.819^{* * *}$ \\
\hline r2_w & & & 0.258 \\
\hline $\mathrm{F}$ & 1510.1 & 61.29 & 90.92 \\
\hline $\mathrm{N}$ & 231 & 231 & 228 \\
\hline
\end{tabular}

Note: The asterisks indicate the significance levels: " $p<0,05,{ }^{\prime \prime} p<0,01, \quad p<0,001$.

\subsection{THE STOCK LIQUIDITY INDEX}

In analyzing the determinants of liquidity expressed by the index proposed in this paper, we followed the methodology in which the models are estimated for portfolios of shares, according to the ranking of the given variable. Based on Fama and French (1993), we divided the sample into portfolios formed from the ranking of the market value of the share and then the book-to-market. This procedure aims to analyze securities from diversified portfolios according to the risk of small firms and the risk of growth firms (with high level of growth opportunities); i.e., the size and growth effects. As the amount of cross-section units used in this study is significantly lower than that of Fama and French (1993), were made up only 10 portfolios, which resulted from the intersection of two groups formed according to the ranking 
of market value and five other groups, constituted according to the growth of the book-tomarket. This procedure is similar to that used by these authors to build risk factors "size" (small minus big) and "growth" (high minus low). As so, in every month were formed independently two portfolios based on the increase of market value and five based on the positive and increasing values of book-to-market ratio. Then, by the intersection between the groups were combined shares of small market capitalization with shares of different levels of growth, yielding 10 portfolios.

The estimations in Table 5 show that liquidity in the domestic market is significantly higher for the shares of companies with an ADR program. That is, a significant positive association is observed between liquidity index (IL) and ADR for portfolios created according to rankings of market value and book-to-market ratio, with the exception of the portfolio $\mathbf{1}$, which consists of shares with lower market capitalization and lower values of book-to-market ratio; and portfolio 6, comprising shares of the group with greater capitalization and lowest book-to-market ratio (TAB. 5). These results suggest that investors perceive and value the higher protection provided by companies with ADRs. The hypothesis of Coffee (2002) seems to apply to the Brazilian case, once the liquidity levels were superior to shares of companies with ADRs, indicating that they require more of these securities.

In addition, the results indicate mostly a positive and significant relationship between levels of governance and liquidity of shares. The results reveal that companies which voluntarily adhere to NM segment are characterized by higher liquidity of its shares. This relationship was shown significant for the two portfolios of shares with lower indicators of market value and book-to-market, and also for all portfolios of shares with the highest capitalization and different levels of book-to-market (TAB. 5). Similar results are observed for N1, with the exception of the portfolio 5, which shows a negative association. For N2, estimates suggest a negative link with the IL for portfolios of stocks with lower market value and different levels of book-to-market, contrary to the expected (TAB 5).

The models in Table 5 are fixed effects. The Hausman test indicates the superiority of this estimator, except for the models (1), (2), (4) and (5); in these cases we chose the fixedeffects estimator that is consistent for both null and alternative hypotheses of the Hausman test. The test of Wooldridge (2002) rejects the null hypothesis of no autocorrelation; and Baum (2001), the homoscedastic variances. Thus, the standard errors were obtained by Driscoll and Kraay (1998) procedure. 
Table 5 - Relationship between IL, ADR and governance levels of the BM\&FBOVESPA

\begin{tabular}{|c|c|c|c|c|c|}
\hline $\begin{array}{l}\text { IL (dependent) } \\
\text { PANEL A }\end{array}$ & (1) & (2) & (3) & (4) & (5) \\
\hline$A D R$ & -0.000534 & $0.00402^{* *}$ & $0.00380^{* * * *}$ & $0.00302^{* *}$ & 0.00106 \\
\hline$N 1$ & $0.000643^{*}$ & $0.000694^{*}$ & 0.000226 & -0.000191 & $-0.00102^{* *}$ \\
\hline$N 2$ & -0.000239 & $-0.00119^{* *}$ & $-0.00193^{* * *}$ & $-0.00283^{* * *}$ & $-0.00283^{* * *}$ \\
\hline$N M$ & $0.00148^{* *}$ & $0.00105^{*}$ & 0.000670 & 0.0000617 & -0.000491 \\
\hline _cons & $0.175^{* * *}$ & $0.175^{* * *}$ & $0.175^{* * *}$ & $0.175^{* * * *}$ & $0.175^{* * *}$ \\
\hline r2_w & 0.000150 & 0.00151 & 0.000781 & 0.000484 & 0.000449 \\
\hline PANEL B & (6) & (7) & (8) & (9) & (10) \\
\hline$A D R$ & $0.00214^{* * *}$ & $0.00210^{* *}$ & $0.00209^{* *}$ & $0.00217^{* * *}$ & $0.00221^{* * *}$ \\
\hline N1 & $0.000955^{* *}$ & $0.000935^{* *}$ & $0.00100^{* *}$ & $0.000823^{*}$ & $0.000726^{*}$ \\
\hline$N 2$ & 0.000587 & 0.000272 & 0.000201 & 0.000212 & 0.000469 \\
\hline$N M$ & $0.00107^{* * *}$ & $0.000653^{*}$ & $0.000803^{*}$ & $0.001000^{* *}$ & $0.00106^{* *}$ \\
\hline _cons & $0.175^{* * *}$ & $0.175^{* * *}$ & $0.175^{* * *}$ & $0.175^{* * *}$ & $0.175^{* * *}$ \\
\hline r2_w & 0.00424 & 0.00326 & 0.00442 & 0.00421 & 0.00346 \\
\hline
\end{tabular}

Note: The asterisks indicate the significance levels: " $p<0,05, "{ }^{\prime \prime \prime} p<0,01, " m<0,001$.

\section{CONCLUSION}

In this study, we sought to identify the determinants of market liquidity of shares traded on the BM\&FBOVESPA. We found several results for the different proxies for liquidity. Mainly, the results revealed that the liquidity of shares increases with the strictest standards of governance, which give higher protection to market investors. The governance increases investors' confidence, which translates into lower spreads. In addition, the trading volume of the shares is higher for companies of special segments of governance on the stock market.

The effect of listing of shares on the North American market through ADRs was ambiguous. As suggested by Moel (2001), the listing of ADR was associated with higher trading costs, measured by the effective spread and bid-ask spread. Ie, the liquidity in the domestic market declined with the listing in other markets. However this result was not robust to alternative proxies of liquidity. And the listing was positively associated to cash trading volume and turnover, indicating greater liquidity.

For the firm level characteristics, the liquidity of assets (financial slack) was associated with lower spreads, corroborating the results of Gopalan, Kadan and Pevzner (2012). The increased liquidity is also associated with the return on the company's sales, suggesting that stocks of companies with better operating performance are more attractive to investors, which is reflected in the levels of liquidity of its shares.

The less liquid shares are the ones that pay more dividends, given the positive relationship between dividend yield and relative bid-ask spread, corroborating the results of Banerjee, Gatchev and Spindt (2007) and Griffin (2010). And the concentration of ownership 
is associated with lower cash trading volumes and turnover, which provides support for the hypothesis that large investors reduce liquidity of shares.

When the stock liquidity was proxied by the index proposed in this paper, which represents different dimensions of liquidity, it was found that the liquidity of the shares in the domestic market increases with the adoption of ADRs. Also, it was observed a positive association between governance and liquidity of shares. In general, companies that voluntarily adhere to the New Market are characterized by higher liquidity of its shares.

Overall, the results testify that well governed companies and that offer higher protection attract more investors, who demand more for their shares. The results of the analysis suggest that investors prefer to invest their funds in well-governed companies, representing significantly more liquid investments that can be traded quickly.

\section{REFERENCES}

AGUIAR, A. B.; CORRAR, L. J.; BATISTELLA, F. D. Adoção de práticas de governança corporativa e o comportamento das ações na Bovespa: evidências empíricas. Revista de Administração da USP, São Paulo, v. 39, n. 4, p. 338-347, 2004.

ALENCAR, R. C. Custo do Capital Próprio e Nível de Disclosure nas Empresas Brasileiras. Brazilian Business Review, v.2, n.1, p. 1-12, 2005.

AMIHUD, Y. Illiquidity and Stock Returns: Cross-Section and Time-Series Effects. Journal of Financial Markets, v. 5, p. 31-56, 2002.

AMIHUD, Y.; MENDELSON, H. Asset pricing and the bid-ask spread. Journal of Finance Economics, v. 17, p. 223-249, dec. 1986.

AMIHUD, Y.; MENDELSON, H. Liquidity and asset price: financial management implications. Financial Management, v. 17, n. 1, p. 5-15, 1988.

AMIHUD, Y.; MENDELSON, H. The liquidity route to a lower cost of capital. Journal of Applied Corporate Finance, v. 12, n. 4, p. 8-25, 2000.

BANERJEE, S.; GATCHEV, V.; SPINDT, P. Stock market liquidity and firm dividend policy. Journal of Financial and Quantitative Analysis, v. 42, n.2, p. 369-398, 2007.

BARBEDO, C. H. S.; SILVA, C. E.; LEAL, R. P. C. Probabilidade de informação privilegiada no mercado de ações, liquidez intra-diária e níveis de governança corporativa. Revista Brasileira de Economia, v.63, n. 1, p. 53-64, 2009.

BAUM, C. F. Residual diagnostics for cross-section time series regression models. Stata Journal, v. 1, n. 1, p. 101-104, 2001.

BRAGA, E.; SECURATO, J. R. Beta e bid-ask spread na determinação do retorno de um título - um estudo setorial. SEMEAD, 2007. 
BRENNAN, M. J. e SUBRAHMANYAM, A. Market microstructure and asset pricing: on the compensation for illiquidity in stock returns. Journal of Financial Economics, v. 41, n. 3, p. 441-464, 1996.

BRUNI, A. L.; FAMÁ, R. Liquidez e avaliação de ativos financeiros: evidências empíricas na Bovespa (1988 - 1996). Anais... XXII Encontro da Associação Nacional de Pós-Graduação e Pesquisa em Administração, Brasil, 1998.

CAO, C.; FIELD, L.; HANKA, G. Does insider trading impair market liquidity? Journal of Financial and Quantitative Analysis, v. 39, n. 1, p. 25-46, 2004.

CARVALHO, A. G. Efeitos da migração para os níveis de Governança da Bovespa. São Paulo: Bovespa, 2003.

CHAVEZ, G. A.; SILVA, A. C. Brazil's experiment with corporate governance. Journal of Applied Corporate Finance, v. 21, n. 1, p. 34-44, 2009.

CHORDIA, T.; ROLL, R.; SUBRAHMANYAM, A. Market liquidity and trading activity. Journal of Finance, v. 56, n. 2, p. 501-530, 2001.

CHORDIA, T.; SARKAR, A.; SUBRAHMANYAM, A. An empirical analysis of stock and bond market liquidity. The Review of Financial Studies, v. 18, n. 1, p. 85-129, 2005.

CHORDIA, T.; ROLL, R.; SUBRAHMANYAM, A. Recent trends in trading activity and market quality. Journal of Financial Economics, v. 101, p. 243-263, 2011.

CHUNG, K. H.; ELDER, J.; KIM, J. C. Corporate governance and liquidity. Journal of Financial and Quantitative Analysis, v. 45, n. 2, p. 265-291, 2010.

COFFEE, J. C. The impact of cross-listing and stock market competition on international governance. Columbia Law Review, v. 102, n. 7, p. 1757-1831, 2002.

CORREIA, L. F.; AMARAL, H. F.; BRESSAN, A. A. O efeito da liquidez sobre a rentabilidade de mercado das ações negociadas no mercado acionário brasileiro. Revista de Administração e Contabilidade da Unisinos, v.5, n.2, p. 109-119, 2008.

CORWIN, S. A. SCHULTZ, P. A simple way to estimate bid-ask spreads from daily high and low prices. Journal of Finance, v. 67, n. 2, p. 719-759, 2012.

DATAR, V. T.; NAIK, N. Y.; RADCLIFFE, R.. Liquidity and stock returns: An alternative test. Journal of Financial Markets, v. 1, p. 203-219, 1998.

DRISCOLL, J. C.; KRAAY, A. C. Consistent Covariance Matrix Estimation with Spatially Dependent Panel Data. Review of Economics and Statistics, v. 80, n. 4, p.549-560, 1998.

FAMA, E. F.; FRENCH, K. Common risk factors in the returns on stocks and bonds. Journal of Financial Economics, v. 33, n. 1, p. 3-56, 1993.

FOERSTER, S. R.; KAROLYI, G. A. Multimarket trading and liquidity: a transaction data analysis of Canada-U.S. interlistings. Journal of International Financial Markets, Institutions and Money, v. 8, n. 3, p. 393-412, 1998. 
FRANCISCO, P. Liquidez e características intrínsecas das acções - o caso do mercado europeu. Cadernos do Mercado de Valores Mobiliários, 2010.

GOH, B. W.; NG, J.; YOUNG, K. O. The effect of corporate governance on liquidity: voluntary disclosure, analyst coverage and adverse selection as mediating mechanisms. Research Collection School of Accountancy Paper, 2009.

GONDRIGE, E. O.; CLEMENTE, A.; ESPEJO, M. M. S. B. Estrutura do conselho de administração e valor das companhias brasileiras. Brazilian Business Review, v.9, n.3, p. 7295, 2012.

GOPALAN, R.; KADAN, O.; PEVZNER, M. Asset Liquidity and Stock Liquidity. Journal of Financial and Quantitative Analysis, v. 47, n.2, p.333-364, 2012.

GRIFFIN, C. H. Liquidity and dividend policy: international evidence. International Business Research, v. 3, n. 3, p. 3-9, 2010.

HOLMSTROM, B.; TIROLE, J. Market liquidity and performance monitoring. Journal of Political Economy, v. 101, n. 11, p. 678-709, 1993.

KALE, R. J.; LOON, Y. C., Product market power and stock market liquidity. Journal of Financial Markets, v. 14, p. 376-410, 2011.

KAROLYI, A. The role of ADRs in the development of emerging equity markets. The Review of Economics and Statistics, v. 86, n. 3, p. 670-690, 2004.

LESMOND, D.; O'CONNOR, P.; SENBET, L. Capital structure and equity liquidity. Working Paper, Tulane University, 2008.

LIPSON, M.; MORTAL, S. Liquidity and capital structure. Journal of Financial Markets, v. 12, p. 611-644, 2009.

MARTINS, V. A.; SILVA, R. L.; NARDI, P. C. C. Governança corporativa e liquidez das ações. In: XXX ENANPAD, Anais..., Salvador, 2006.

MACHADO, M. A. V.; MEDEIROS, O. R. Existe o efeito liquidez no mercado acionário brasileiro? Brazilian Business Review, v.9, n.4, p. 28-51, 2012.

MOEL, A. The role of American Depositary Receipts in the development of emerging markets, Economia, v. 2, n. 1, p.209-257, 2001.

NAGAR, A. L.; BASU, S.R. Weighting socio-economic indicators of human development: a latent variable approach. In: ULLAH et al. (org.). Handbook of applied econometrics and statistical inference. New York, Marcel Dekker, 2002. Cap. 29.

NEVES, L.; LEMES, C. Efeitos no retorno e na liquidez média das ações de empresas que emitiram ADRs na NYSE e das que aderiram ao Novo Mercado. Revista Universo Contábil, v. 5, n. 3, p. 24-42, jul./set. 2009.

PAGANO, M.; ROELL, A.; ZECHNER, J. The geography of equity listing: why do companies list abroad? Journal of Finance, v. 57, n. 6, p. 2651-2694, 2002. 
PROCIANOY, J. L.; VERDI, R. S. Adesão aos novos mercados da Bovespa: novo mercado, nível 1 e nível 2. Revista Brasileira de Finanças, v. 7, n. 1, p. 107-136, 2009.

RODRIGUES, E. L. Maior visibilidade ou integração do mercado de capitais brasileiro? Revista da CVM, p. 39-51, dez. 1999.

RUBIN, A. Ownership level, ownership concentration and liquidity. Journal of Financial Markets, v. 10, p. 219-248, 2007.

SANVICENTE, A. Z. O mercado de ADRs e a qualidade do mercado de ações no Brasil. Working Paper, Faculdade Ibmec, 2001.

SHLEIFER, A.; VISHNY, R. W. A survey of corporate governance. Journal of Finance, v. 52, n. 2, p. 737-783, 1997.

VIEIRA, K. M.; MILACH, F. T.; Liquidez/Iliquidez no mercado brasileiro: comportamento no período 1995-2005 e suas relações com o retorno. Revista de Administração e Contabilidade da Unisinos, v. 5, n. 1, p. 5-16, 2008.

VIEIRA, K. M.; CERETTA, P. S.; FONSECA, J. L. Influência da variação da liquidez na precificação de ativos: análise em painel do mercado brasileiro no período de janeiro de 2000 a junho de 2008. Brazilian Business Review, v. 8, n.3, p. 41-65, 2011.

WOOLDRIDGE, J. M. Econometric analysis of cross section and panel data. Cambridge, 2002. 